\title{
Reply: Comment on 'Elevated preoperative neutrophil/lymphocyte ratio is associated with poor prognosis in soft-tissue sarcoma patients'
}

\author{
J Szkandera ${ }^{1}$, M Pichler ${ }^{1}$, A Gerger ${ }^{*}, 1$ and A Leithner ${ }^{2}$ \\ ${ }^{1}$ Division of Clinical Oncology, Department of Medicine, Medical University of Graz, Auenbruggerplatz 15, 8036 Graz, Austria and \\ ${ }^{2}$ Department of Orthopaedic Surgery, Medical University of Graz, Auenbruggerplatz 15, 8036 Graz, Austria
}

Sir

We would like to thank Bhat et al (2013) for their interesting comments and suggestions regarding our manuscript 'Elevated preoperative neutrophil/lymphocyte $(\mathrm{N} / \mathrm{L})$ ratio is associated with poor prognosis in soft-tissue sarcoma patients'. We demonstrated that the $\mathrm{N} / \mathrm{L}$ ratio is an independent prognostic marker for time to recurrence (TTR) and overall survival (OS) in a large cohort of patients with soft-tissue sarcoma (STS) (Szkandera et al, 2013). The $\mathrm{N} / \mathrm{L}$ ratio is a cost-effective and easily determinable potential prognostic marker. Previous studies, including cardiovascular diseases and various cancer entities, showed a poor clinical outcome in patients presenting with an elevated pre-treatment N/L ratio (Bhat et al, 2013; Guthrie et al, 2013; Pichler et al, 2013). In general, it is supposed to reflect the systemic inflammatory response that accompanies chronic diseases, but might be influenced by many different factors, including systemic infections, atherosclerosis, hypertension, chronic renal diseases and diabetes and can be even affected by atherosclerotic risk factors and drug treatment (Buyukkaya et al, 2012; Kaya et al, 2013; Lee et al, 2012; Demir, 2013; Okyay et al, 2013). We are aware that these parameters might influence the balance between cells of the white blood cell count, especially neutrophils and lymphocytes, but most of these factors were not available for analysis in our study cohort. However, as the laboratory data, including neutrophil and leucocyte counts, were obtained by exploration within 3 days before surgery, at least acute conditions like bacterial or viral infections that would probably influence the N/L ratio can be excluded. We concur with Balta et al (2013) that the potential confounding factors mentioned above should be considered in further prospective studies investigating inflammatory biomarkers in various diseases to elucidate their true prognostic impact.

\section{CONFLICT OF INTEREST}

The authors declare no conflict of interest.

\section{REFERENCES}

Balta S, Demirkol S, Sarlak H, Kurt O (2013) Comment on 'Elevated preoperative neutrophil/lymphocyte ratio is associated with poor prognosis in soft-tissue sarcoma patients': neutrophil to lymphocyte ratio may be predictor of mortality in patients with soft-tissue sarcoma. Br J Cancer 108(12): 2625-2626.

Bhat T, Teli S, Rijal J, Bhat H, Raza M, Khoueiry G, Meghani M, Akhtar M, Costantino T (2013) Neutrophil to lymphocyte ratio and cardiovascular diseases: a review. Expert Rev Cardiovasc Ther 11: 55-59.

Buyukkaya E, Karakas MF, Karakas E, Akçay AB, Kurt M, Tanboga IH, Sen N (2012) Correlation of neutrophil to lymphocyte ratio with the presence and severity of metabolic syndrome. Clin Appl Thromb Hemost; e-pub ahead of print 18 September 2012.

Demir M (2013) The Relationship Between Neutrophil Lymphocyte Ratio and Non-dipper Hypertension. Clin Exp Hypertens; e-pub ahead of print 6 February 2013.

Guthrie GJ, Charles KA, Roxburgh CS, Horgan PG, McMillan DC, Clarke SJ (2013) The systemic inflammation-based neutrophil-lymphocyte ratio: experience in patients with cancer. Crit Rev Oncol Hematol; e-pub ahead of print 16 April 2013; pii: S1040-8428(13)00070-X.

Kaya H, Ertas F, Islamoglu Y, Kaya Z, Atilgan ZA, Cil H, Caliskan A, Aydin M, Oylumlu M, Soydinç MS (2013) Association between neutrophil to lymphocyte ratio and severity of coronary artery disease. Clin Appl Thromb Hemost; e-pub ahead of print 7 May 2013.

Lee GK, Lee LC, Chong E, Lee CH, Teo SG, Chia BL, Poh KK (2012) The longterm predictive value of the neutrophil-to-lymphocyte ratio in Type 2 diabetic patients presenting with acute myocardial infarction. QJM 105: 1075-1082.

Okyay GU, Inal S, Oneç K, Er RE, Paşaoğlu O, Paşaoğlu H, Derici U, Erten Y (2013) Neutrophil to lymphocyte ratio in evaluation of inflammation in patients with chronic kidney disease. Ren Fail 35: 29-36.

Pichler M, Hutterer GC, Stoeckigt C, Chromecki TF, Stojakovic T, Golbeck S, Eberhard K, Gerger A, Mannweiler S, Pummer K, Zigeuner R (2013) Validation of the pre-treatment neutrophil-lymphocyte ratio as a prognostic factor in a large European cohort of renal cell carcinoma patients. Br J Cancer 108: 901-907.

Szkandera J, Absenger G, Liegl-Atzwanger B, Pichler M, Stotz M, Samonigg H, Glehr M, Zacherl M, Stojakovic T, Gerger A, Leithner A (2013) Elevated preoperative neutrophil/lymphocyte ratio is associated with poor prognosis in soft-tissue sarcoma patients. Br J Cancer 108(8): 1677-1683. 